\title{
Perancangan Media Penjualan Produk Pada Toko Tina Tailor Berbasis Mobile Web
}

\author{
Larasati Lugi Aryaningsih ${ }^{a}$ Sari Setyaning Tyas, M.Ti ${ }^{b}$ Rudy Cahyadi, $M T^{c}$
}

${ }^{\mathrm{c}}$ Politeknik Negeri Media Kreatif

\section{INFORMASI ARTIKEL}

Sejarah Artikel:

Diterima Redaksi: 04 November 2021

Revisi Akhir: 10 Desember 2021

Diterbitkan Online: 15 Desember 2021

KATA KUnCI
$\begin{aligned} & \text { E-Commerce, Tina } \\ & \text { Website }\end{aligned}$

KORESPONDENSI

Email : larasatilugi@gmail.com

\section{ABSTRACT}

Salah satu aktivitas yang menggunakan media internet dalam mengembangkan penjualannya yaitu dengan e-commerce, sama halnya dengan bisnis online. Lain halnya dengan Tina Tailor, belum mengoptimalkan penjualannya secara online dan media informasi pada Tina Tailor masih menggunakan perantara via WhatsApp. Solusi yang diberikan untuk permasalah pada toko Tina Tailor yaitu menambah media penjualan dengan sistem digitalisasi berbasis mobile website menggunakan WordPress dengan plugin WooCommerce. Metode perancangan sistem menggunakan Entity Relationship Diagram (ERD) dan Unified Modeling Language (UML). Pengujian mobile web menggunakan metode black box untuk uji fungsional dan sebaran kuesioner untuk usability test. Hasil pengujian fungsionalitas memperlihatkan data masukan dengan hasil yang diinginkan telah selaras. Hasil pengujian kompatibilitas menunjukan hasil kecepatan yang baik. Hasil pengujian usability mobile web Tina Tailor mencapai 92.36\% menunjukan bahwa mobile web Tina Tailor sangat layak digunakan oleh pengguna sebagai media penjualan.

DOI: $10.46961 /$ jommit.v5i2

\section{PENDAHULUAN}

Kemajuan dalam bidang teknologi, informasi dan komunikasi membuat kehidupan berubah dan meningkat pesat. Hampir di setiap sektor telah terkoneksi dengan internet. Jumlah masyarakat yang menggunakan internet di Indonesia, berdasarkan riset We Are Social[1], telah mencapai 175,4 juta pengguna. Sebenarnya, pengguna internet mobile jauh lebih banyak nyaris dua kali lipatnya. Sekarang dicatatkan masyarakat Indonesia yang memakai koneksi internet pada perangkat mobile, semacam smartphone ataupun tablet, mencapai 338,2 juta pengguna.

Salah satu aktivitas yang dilakukan dengan menggunakan media internet dalam mengembangkan penjualannya yaitudengan e-commerce, adalah sejenis marketplace tempat dimana transaksi bisnis online terjadi. Semakin maraknya penggunaan smartphone, calon pembeli ataupun konsumen bisa menemui laman penjual, mencari produk, membandingkan, berinteraksi dan memesan secara online. Pemakaian e-commerce lebih banyak memberi keuntungan apabila dibandingkan dengan cara membeli yang konvensional[2].

Tina Tailor merupakan sebuah usaha yang menjual jasa jahit pakaian. Selain jasa jahit pakaian, Tina Tailor menjual produk pakaian. Media penjualan yang dilakukan oleh Tina Tailor pada awalnya sebatas offline dan masih bersifat konvensional hanya dengan memberikan informasi produk dari mulut ke mulut, dan konsumen mendatangi langsung toko. Pada layanan custom pakaian, berdasarkan keterangan dari pengunjung toko mengungkapkan bahwa kurangnya media informasi untuk penjadwalan dikarenakan pada saat pengunjung datang ke toko untuk custom pakaian, pemilik sering kali tidak berada di tempat. Setelah Tina Tailor mengeluarkan produk pakaian sehingga mulai merambah media penjualan online melalui media sosial Instagram. Pemilik toko Tina Tailor menggunakan media sosial instagram untuk menaikan volume penjualan. Berikut tabel penjualan yang dimiliki oleh toko Tina Tailor dengan menggunakan instagram dan metode oflline pada tahun 2020 . 


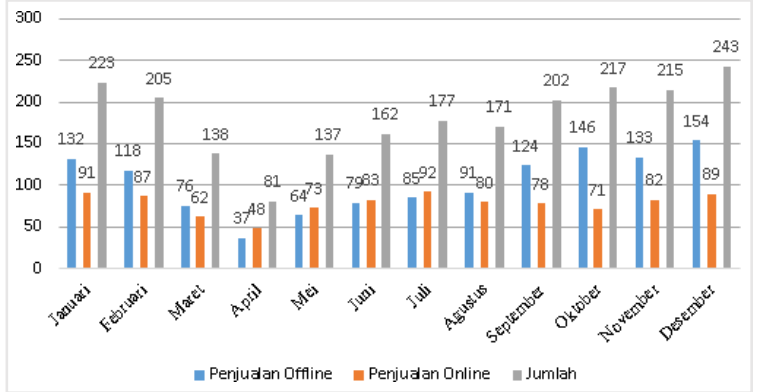

Gambar 1. Data Penjualan

Gambar diatas menunjukkan bahwa penjualan toko Tina Tailor mengalami peningkatan walaupun sempat ada penurunan volume penjualan yang signifikan pada bulan april dikarenakan adanya dampak peraturan terkait Covid-19. Jumlah penjualan tersebut dibagi berdasarkan penjualan online menggunakan instagram dan penjualan offline. Gambar diatas menunjukkan bahwa penjualan online belum dapat mempengaruhi penjualan jika di bandingkan dengan penjualan offline. Dalam hal ini, penjualan online melalui instagram tidak berjalan seperti yang diharapankan oleh pemilik toko Tina Tailor. Jika total penjualan dihitung terlepas dari metode penjualan yang digunakan, penjualan toko Tina Tailor rata-rata meningkat dari waktu ke waktu.

Penjualan online melalui Instagram mengambil peran dalam perwujudan kegiatan penjualan, tetapi akun instagram yang digunakan semata-mata hanya untuk memberi informasi tentang produk, sehingga sedikit yang melanjutkan sampai ketahap pembelian produk. Selain itu untuk mengetahui informasi stok produk yang tersedia, konsumen masih perlu menghubungi penjual melalui perantara via WhatsApp. Hal tersebut menjadi penghambat pelayanan dan informasi yang diterima oleh konsumen. Dengan demikian, toko Tina Tailor memiliki kekurangan dalam mengoptimalkan penjualan produk secara online dan juga kurangnya media informasi untuk layanan custom pakaian, sehingga proses penjualan yang dilakukan belum optimal.

Penulis memberikan solusi yaitu dengan membantu Tina Tailor menambah media penjualan dengan sistem digitalisasi sehingga terciptanya mobile website yang dapat diakses oleh pelanggan dengan mudah melalui smartphone yang terhubung dengan internet yang dapat diakses tanpa adanya batasan waktu. Penulis mengupayakan dengan pembuatan mobile website dapat memberikan hasil yang dapat membantu usaha Tina Tailor untuk menciptakan dan mendapatkan keuntungan dengan menyediakan wadah bagi produk dan layanan yang tersedia.

\section{TINJAUAN PUSTAKA}

\subsection{Penjualan}

Kegiatan penjualan akan menjadi lengkap apabila terdapat pembelian, buat membentuk suatu transaksi terjadi. Aktivitas penjualan akan terjadi apabila ada pembeli dan terjadinya suatu transaksi, yang dapat diakhiri melalui proses pembayaran[3].

\subsection{E-Commerce}

E-commerce kependekan dari electronic commerce atau perdagangan elektronik adalah penyebaran, pembelian, penjualan, pemasaran barang dan jasa melalui internet atau jaringan komputer. Seluruh komponen yang terdapat pada perdagangan diterapkan ke dalam e-commerce, misalnya cara pembayaran, layanan produk dan promosi. Menggunakan $e$ commerce adalah kebutuhan penting bagi sebuah bisnis supaya bisa bersaing secara global[4].

\subsection{Key Point E-Commerce}

Banyak pelangan berbelanja online demi kenyamanan. Sebagai pemilik bisnis, harus membuat segalanya lebih mudah bagi pembeli. Untuk mempengaruhi pembeli dan melakukan penjualan, situs e-commerce yang dibuat harus mudah digunakan dan menerapkan beberapa point. Berikut adalah hal yang perlu dipertimbangkan Ketika mengembangkan atau merestrukturisasi situs e-commerce yaitu User Friendly, Shopping Cart and Checkout Process, Mobile Compatibility, Call to Action (CTA), Images and Descriptions, In Stock, Customer Support, Security and Privacy.

\subsection{Mobile Website}

Mobile website merupakan situs yang didesain spesifik buat perangkat selular yang didesain memakai standard yang sama dengan website pada desktop. Beberapa aspek yang wajib diperhatikan pada perancangan mobile website yaitu keterbatasakan fisik, mencakup bentuk fisik yang mini dan inputan terbatas. Selain itu keterbatasan teknis, mencakup taraf keamanan yang terbatas, faktor device yang bervariasi, input yang bervariasi misalnya layer sentuh, numeric keypad, qwerty keypad, dan akses data yang bervariasi[5].

\subsection{Mobile Website Development}

Mobile website pada dasarnya sama dengan situs web biasa, satusatunya pengecualian adalah ukurannya disesuaikan, biasanya menggunakan desain responsif untuk menyesuaikan tata letak agar sesuai dengan ukuran layar yang lebih kecil dari perangkat seluler yang sedang dilihat. Dilansir dari halaman website Developer Mozilla[6] terdapat beberapa teknik utama yang diperlukan untuk merancang situs web yang berfungsi dengan baik di perangkat seluler yaitu designing for mobile devices dan cross browser compatibility.

\section{6. $E R D$}

Entity Relationship Diagram (ERD) adalah suatu cara untuk menjelaskan kepada para pemakai tentang dokumentasi yang digunakan untuk menyajikan relasi, dan tentang hubungan antar data secara logic.

\section{7. $U M L$}

UML (Unified Modeling Language) adalah sebuah bahasa yang berdasarkan grafik atau gambar untuk memvisualisasi, menspesifikasikan, membangun, dan pendokumentasian dari sebuah sistem pengembangan software berbasis Object-Oriented. UML sendiri juga memberikan standar penulisan sebuah sistem blue print, yang meliputi konsep bisnis proses, penulisan kelaskelas dalam bahasa program yang spesifik, skema database, dan komponen-komponen yang diperlukan dalam sistem software[7] 


\section{KONSEP PERANCANGAN}

Penulis menggunakan UML dan ERD yang akan digunakan untuk memaparkan mengenai alur sistem yang akan dibuat pada karya ini.

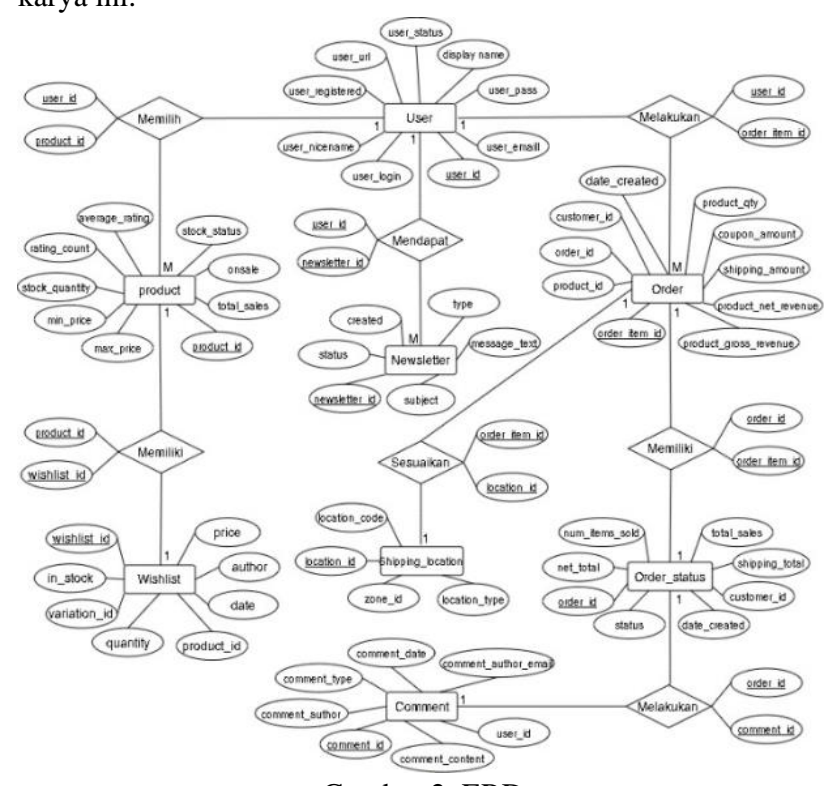

Gambar 2. ERD

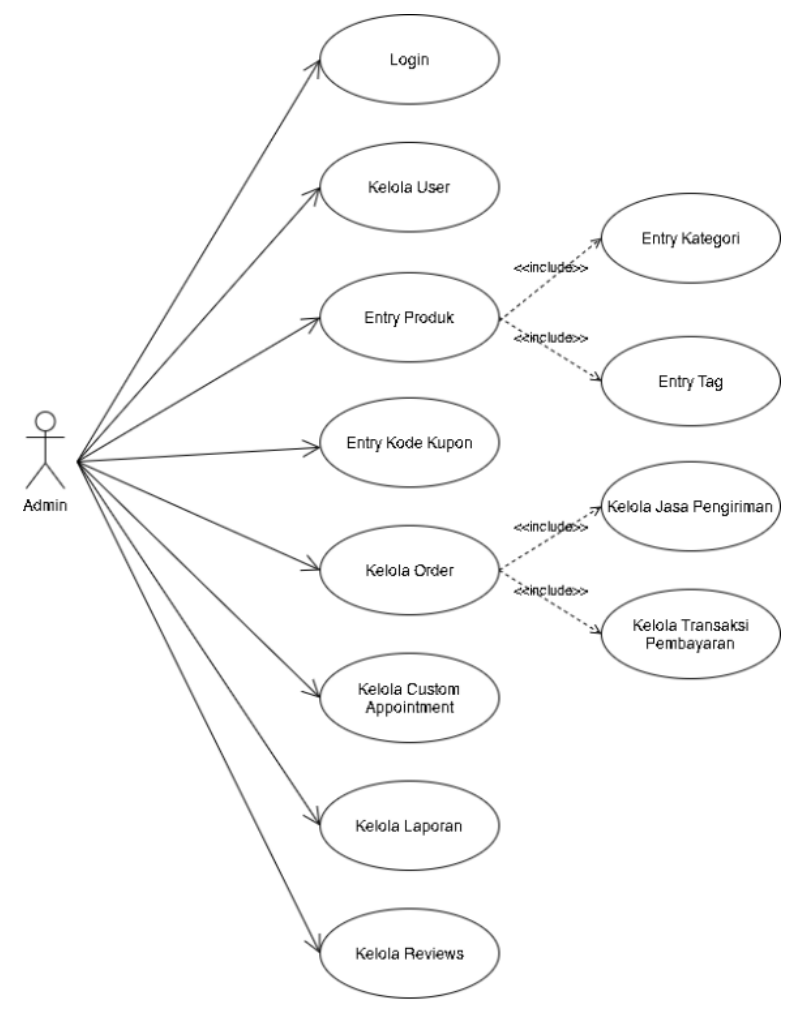

Gambar 3. Use Case Diagram Admin

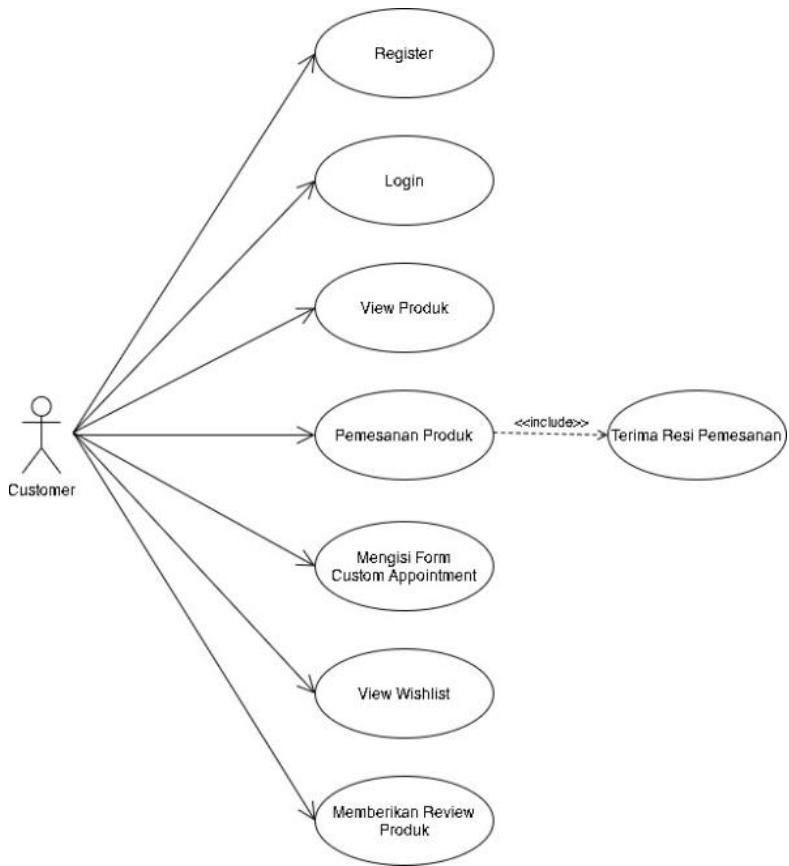

Gambar 4. Use Case Diagram Customer

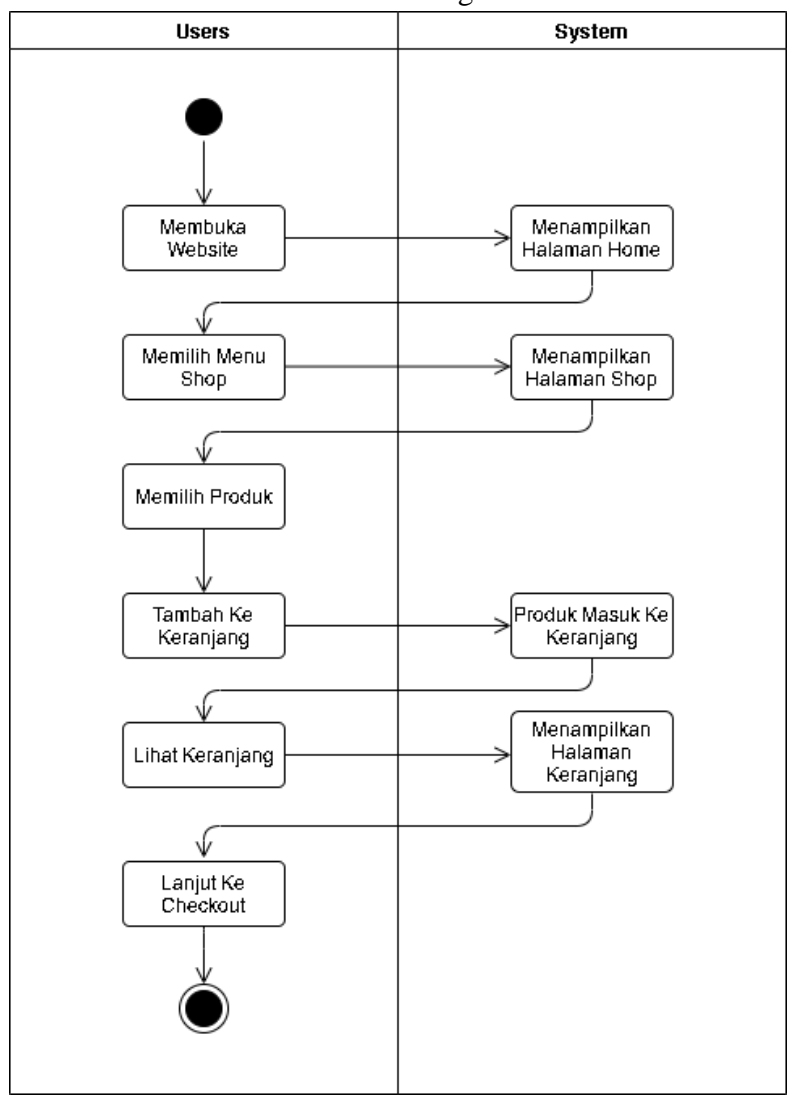

Gambar 5. Activity Diagram Pemesanan 


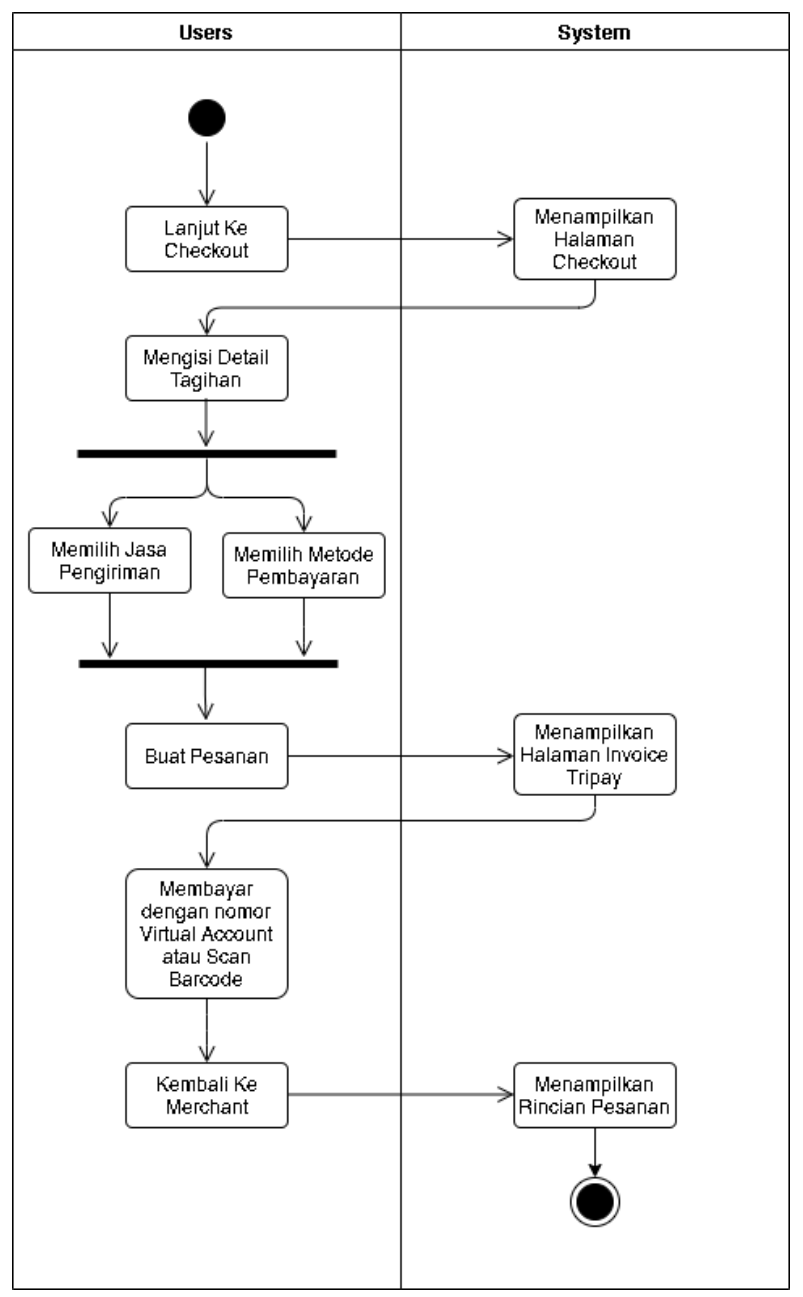

Gambar 6. Activity Diagram Pembayaran
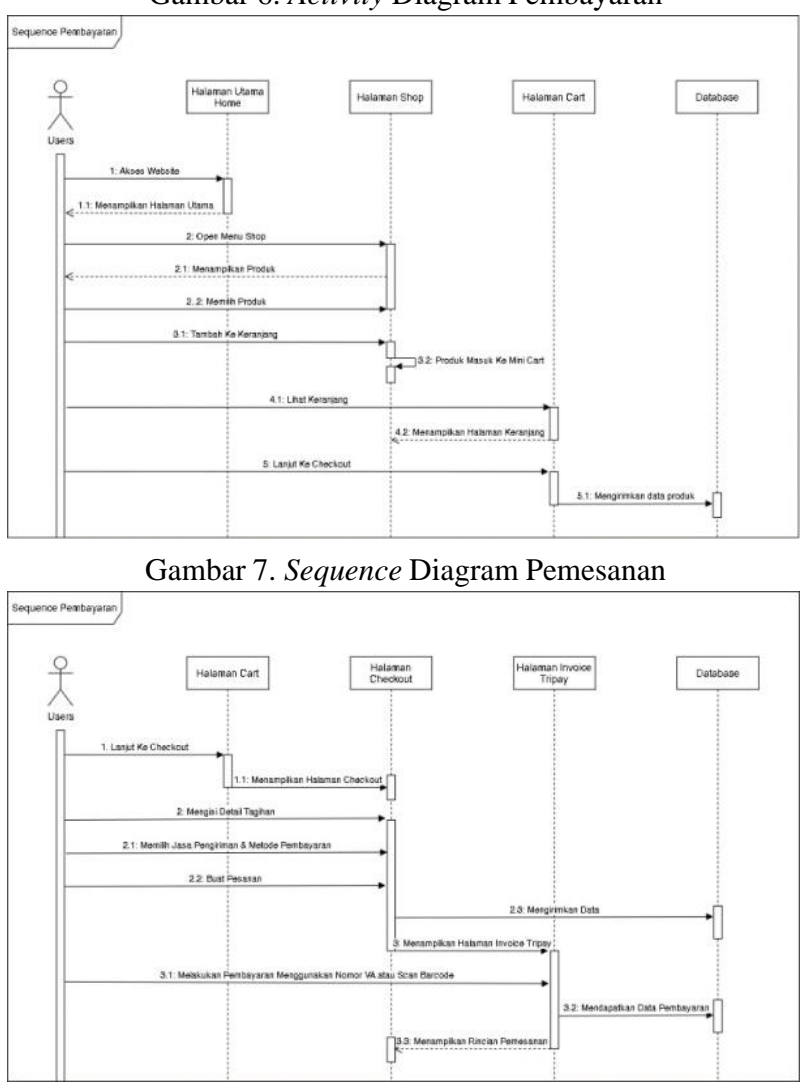

Gambar 8. Sequence Diagram Pembayaran
4. HASIL DAN PEMBAHASAN

\subsection{Tampilan Mobile Website Tina Tailor}
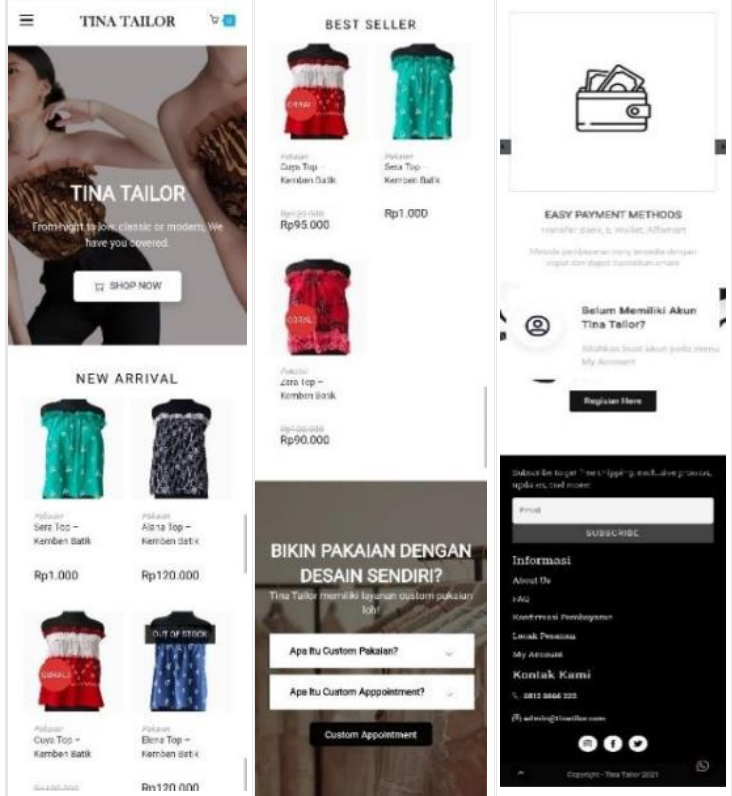

Gambar 9. Tampilan Halaman Utama

\subsection{Pengujian Sistem}

Pengujian dilakukan dengan menguji setiap proses dan kemungkinan kesalahan yang terjadi untuk setiap proses. Adapun pengujian sistem yang dilakukan, yaitu uji fungsi website, uji kompatibilitas, dan uji kebergunaan website.

Tabel 1. Hasil Function Test

\begin{tabular}{|c|c|c|c|c|}
\hline \multicolumn{5}{|c|}{ Kasus dan Hasil Uji (Data Benar) } \\
\hline \multirow{2}{*}{$\begin{array}{l}\text { Data } \\
\text { Masukan }\end{array}$} & \multirow{2}{*}{$\begin{array}{l}\text { Yang } \\
\text { Diharapkan }\end{array}$} & \multirow[t]{2}{*}{ Pengamatan } & \multicolumn{2}{|l|}{ Hasil } \\
\hline & & & Passed & Fail \\
\hline $\begin{array}{l}\text { Menu } \\
\text { shop } \\
\text { dipilih }\end{array}$ & $\begin{array}{l}\text { Akan tampil } \\
\text { halaman shop } \\
\text { berisi foto-foto } \\
\text { produk, user } \\
\text { memilih produk, } \\
\text { data akan masuk } \\
\text { kedalam } \\
\text { keranjang }\end{array}$ & $\begin{array}{l}\text { Tampil } \\
\text { halaman } \\
\text { shop berisi } \\
\text { foto-foto } \\
\text { produk, } \\
\text { user } \\
\text { memilih } \\
\text { produk data } \\
\text { yang dipilih } \\
\text { masuk ke } \\
\text { dalam } \\
\text { keranjang }\end{array}$ & $\checkmark$ & \\
\hline $\begin{array}{l}\text { Icon mini } \\
\text { cart } \\
\text { dipilih }\end{array}$ & $\begin{array}{lr}\text { Akan } & \text { tampil } \\
\text { produk } & \text { yang } \\
\text { dipilih, button } & \\
\text { lihat keranjang } \\
\text { dan pembayaran }\end{array}$ & $\begin{array}{l}\text { Tampil } \\
\text { produk } \\
\text { yang } \\
\text { dipilih, } \\
\text { button lihat } \\
\text { keranjang } \\
\text { dan } \\
\text { pembayaran }\end{array}$ & $\checkmark$ & \\
\hline $\begin{array}{l}\text { Button } \\
\text { lihat } \\
\text { keranjang } \\
\text { dipilih }\end{array}$ & $\begin{array}{l}\text { Akan tampil } \\
\text { halaman } \\
\text { keranjang dan } \\
\text { detail produk }\end{array}$ & $\begin{array}{l}\text { Tampil } \\
\text { halaman } \\
\text { keranjang } \\
\text { dan detail } \\
\text { produk }\end{array}$ & $\checkmark$ & \\
\hline
\end{tabular}


Tabel 2. Hasil Comptable Test

\begin{tabular}{|c|c|c|c|c|}
\hline \multirow[b]{2}{*}{ Proses Pengujian } & \multicolumn{4}{|c|}{ Perangkat Smartphone } \\
\hline & $\begin{array}{l}\text { Vivo } \\
\text { V15 }\end{array}$ & $\begin{array}{c}\text { Xiaomi } \\
\text { Poco } \\
\text { F2 }\end{array}$ & $\begin{array}{c}\text { Iphone } \\
7\end{array}$ & $\begin{array}{c}\text { Iphone } \\
11\end{array}$ \\
\hline Network & Wi-Fi & Wi-Fi & Wi-Fi & $4 \mathrm{G}$ \\
\hline Browser Load & Chrome & Chrome & Safari & Safari \\
\hline $\begin{array}{l}\text { Durasi sampai ke } \\
\text { halaman utama }\end{array}$ & $\begin{array}{c}4.1 \\
\text { detik }\end{array}$ & $\begin{array}{c}3.6 \\
\text { detik }\end{array}$ & $\begin{array}{c}4.4 \\
\text { detik }\end{array}$ & $\begin{array}{c}3.8 \\
\text { detik }\end{array}$ \\
\hline Menu Shop & $\begin{array}{c}3.5 \\
\text { detik }\end{array}$ & $\begin{array}{c}2.9 \\
\text { detik }\end{array}$ & 4 detik & $\begin{array}{c}3.4 \\
\text { detik }\end{array}$ \\
\hline Menu Custom & $\begin{array}{c}3.1 \\
\text { detik }\end{array}$ & 2 detik & $\begin{array}{c}3.4 \\
\text { detik }\end{array}$ & $\begin{array}{c}3.7 \\
\text { detik }\end{array}$ \\
\hline $\begin{array}{ll}\text { Menu } & \text { My } \\
\text { Account } & \end{array}$ & $\begin{array}{l}2.04 \\
\text { detik }\end{array}$ & $\begin{array}{c}1.9 \\
\text { detik }\end{array}$ & $\begin{array}{c}2.6 \\
\text { detik }\end{array}$ & $\begin{array}{c}2.4 \\
\text { detik }\end{array}$ \\
\hline $\begin{array}{l}\text { Menu Konfirmasi } \\
\text { Pembayaran }\end{array}$ & $\begin{array}{l}4.05 \\
\text { detik }\end{array}$ & $\begin{array}{c}3.2 \\
\text { detik }\end{array}$ & $\begin{array}{c}4.1 \\
\text { detik }\end{array}$ & $\begin{array}{c}3.6 \\
\text { detik }\end{array}$ \\
\hline Menu Wishlist & $\begin{array}{c}3.8 \\
\text { detik }\end{array}$ & $\begin{array}{c}3.3 \\
\text { detik }\end{array}$ & $\begin{array}{c}3.9 \\
\text { detik }\end{array}$ & $\begin{array}{l}4.01 \\
\text { detik }\end{array}$ \\
\hline $\begin{array}{ll}\text { Menu } & \text { Lacak } \\
\text { Pesanan } & \\
\end{array}$ & $\begin{array}{c}3.6 \\
\text { detik }\end{array}$ & $\begin{array}{c}3.2 \\
\text { detik }\end{array}$ & $\begin{array}{c}3.4 \\
\text { detik }\end{array}$ & $\begin{array}{c}4.3 \\
\text { detik }\end{array}$ \\
\hline Menu Contact & $\begin{array}{c}4.1 \\
\text { detik } \\
\end{array}$ & $\begin{array}{c}2.7 \\
\text { detik }\end{array}$ & $\begin{array}{c}3.3 \\
\text { detik }\end{array}$ & $\begin{array}{c}3.8 \\
\text { detik } \\
\end{array}$ \\
\hline Menu About & $\begin{array}{c}3.9 \\
\text { detik }\end{array}$ & $\begin{array}{c}3.4 \\
\text { detik }\end{array}$ & $\begin{array}{c}4.5 \\
\text { detik }\end{array}$ & $\begin{array}{c}4.2 \\
\text { detik }\end{array}$ \\
\hline Mesin Pencarian & $\begin{array}{c}3.3 \\
\text { detik }\end{array}$ & $\begin{array}{c}2.4 \\
\text { detik }\end{array}$ & $\begin{array}{c}2.9 \\
\text { detik }\end{array}$ & $\begin{array}{c}3.5 \\
\text { detik }\end{array}$ \\
\hline Melihat Produk & $\begin{array}{c}2.6 \\
\text { detik }\end{array}$ & 2 detik & $\begin{array}{c}2.3 \\
\text { detik }\end{array}$ & 3 detik \\
\hline Mini Cart & $\begin{array}{l}0.81 \\
\text { detik }\end{array}$ & $\begin{array}{l}0.48 \\
\text { detik }\end{array}$ & $\begin{array}{l}0.73 \\
\text { detik }\end{array}$ & $\begin{array}{l}0.62 \\
\text { detik }\end{array}$ \\
\hline Luas Layar & Baik & Baik & Baik & Baik \\
\hline $\begin{array}{l}\text { Kejernihan } \\
\text { Gambar }\end{array}$ & Baik & Baik & Baik & Baik \\
\hline $\begin{array}{l}\text { Kelengkapan } \\
\text { Tampilan }\end{array}$ & Baik & Baik & Baik & Baik \\
\hline
\end{tabular}

Tabel 3. Hasil Usability Test

\begin{tabular}{|c|c|c|c|}
\hline \multicolumn{4}{|c|}{ Hasil Pengujian Aspek Learnability } \\
\hline Kode & Pernyataan & $\begin{array}{l}\text { Total } \\
\text { Skor }\end{array}$ & $\begin{array}{l}\text { Skor } \\
\text { Max }\end{array}$ \\
\hline P1 & $\begin{array}{l}\text { Saya mampu dengan mudah } \\
\text { mengerti alur dari navigasi } \\
\text { yang ada pada mobile web } \\
\text { Tina Tailor }\end{array}$ & 137 & 150 \\
\hline $\mathrm{P} 2$ & $\begin{array}{l}\text { Saya mampu dengan mudah } \\
\text { memahami menu-menu } \\
\text { yang tersedia pada mobile } \\
\text { web Tina Tailor }\end{array}$ & 134 & 150 \\
\hline P3 & $\begin{array}{l}\text { Saya mampu dengan mudah } \\
\text { memahami tulisan teks yang } \\
\text { digunakan secara jelas pada } \\
\text { mobile web Tina Tailor }\end{array}$ & 143 & 150 \\
\hline $\mathrm{P} 4$ & $\begin{array}{l}\text { Saya mampu dengan mudah } \\
\text { memahami simbol, ikon, } \\
\text { dan gambar yang ada pada } \\
\text { mobile web Tina Tailor }\end{array}$ & 137 & 150 \\
\hline P5 & $\begin{array}{l}\text { Saya mampu dengan mudah } \\
\text { menemukan tombol search }\end{array}$ & 135 & 150 \\
\hline
\end{tabular}

\begin{tabular}{|c|c|c|c|}
\hline & $\begin{array}{l}\text { pada mobile web Tina } \\
\text { Tailor }\end{array}$ & & \\
\hline P6 & $\begin{array}{l}\text { Saya mampu dengan mudah } \\
\text { mengakses informasi } \\
\text { produk yang ditawarkan } \\
\text { pada mobile web TinaTailor }\end{array}$ & 141 & 150 \\
\hline \multicolumn{4}{|c|}{ Hasil Pengujian Aspek Efficiency } \\
\hline$\overline{\mathrm{P} 7}$ & $\begin{array}{l}\text { Saya mampu dengan mudah } \\
\text { memahami tampilan } \\
\text { website secara cepat pada } \\
\text { mobile web Tina Tailor }\end{array}$ & 140 & 150 \\
\hline P8 & $\begin{array}{l}\text { Saya mampu dengan mudah } \\
\text { mengakses menu-menuyang } \\
\text { tersedia secara cepat pada } \\
\text { mobile web Tina } \\
\text { Tailor }\end{array}$ & 141 & 150 \\
\hline P9 & $\begin{array}{l}\text { Saya mampu dengan mudah } \\
\text { memperoleh informasi } \\
\text { produk secara cepat pada } \\
\text { mobile web Tina Tailor }\end{array}$ & 140 & 150 \\
\hline P10 & $\begin{array}{l}\text { Saya mampu dengan mudah } \\
\text { memperoleh hasil pencarian } \\
\text { produk secara cepat pada } \\
\text { mobile web Tina Tailor }\end{array}$ & 137 & 150 \\
\hline P11 & $\begin{array}{l}\text { Saya mampu dengan mudah } \\
\text { melakukan transaksi } \\
\text { pembayaran secara cepat } \\
\text { pada mobile web TinaTailor }\end{array}$ & 136 & 150 \\
\hline \multicolumn{4}{|c|}{ Hasil Pengujian Aspek Memorability } \\
\hline $\mathrm{P} 12$ & $\begin{array}{l}\text { Saya mampu dengan mudah } \\
\text { mengingat arah navigasi } \\
\text { pada mobile web TinaTailor }\end{array}$ & 128 & 150 \\
\hline $\mathrm{P} 13$ & $\begin{array}{l}\text { Saya mampu dengan mudah } \\
\text { mengingat menu-menu } \\
\text { yang tersedia pada mobile } \\
\text { web Tina Tailor }\end{array}$ & 139 & 150 \\
\hline $\mathrm{P} 14$ & $\begin{array}{l}\text { Saya mampu dengan mudah } \\
\text { mengingat tampilan dari } \\
\text { halaman yang tersedia pada } \\
\text { mobile web Tina Tailor }\end{array}$ & 143 & 150 \\
\hline \multicolumn{4}{|c|}{ Hasil Pengujian Aspek Errors } \\
\hline $\mathrm{P} 15$ & $\begin{array}{l}\text { Saya tidak menemukan } \\
\text { menu yang error pada } \\
\text { mobile web Tina Tailor }\end{array}$ & 144 & 150 \\
\hline $\mathrm{P} 16$ & $\begin{array}{l}\text { Saya tidak menemukan } \\
\text { error saat melakukan } \\
\text { transaksi pembayaran pada } \\
\text { mobile web Tina Tailor }\end{array}$ & 137 & 150 \\
\hline $\mathrm{P} 17$ & $\begin{array}{l}\text { Saya tidak menemukan saat } \\
\text { menu diklik tidak } \\
\text { memberikan respon pada } \\
\text { mobile web Tina Tailor }\end{array}$ & 144 & 150 \\
\hline \multicolumn{4}{|c|}{ Hasil Pengujian Aspek Satisfaction } \\
\hline $\mathrm{P} 18$ & $\begin{array}{l}\text { Saya merasa nyaman dalam } \\
\text { mengoperasikan mobile } \\
\text { web Tina Tailor }\end{array}$ & 140 & 150 \\
\hline P19 & $\begin{array}{l}\text { Saya merasa nyaman } \\
\text { dengan tampilan, paduan } \\
\text { warna dan tata letak konten } \\
\text { secara keseluruhan pada } \\
\text { mobile web Tina Tailor }\end{array}$ & 142 & 150 \\
\hline
\end{tabular}




\begin{tabular}{|l|l|l|l|}
\hline P20 & $\begin{array}{l}\text { Saya akan mengunjungi } \\
\text { kembali mobile web Tina } \\
\text { Tailor }\end{array}$ & 133 & 150 \\
\hline \multicolumn{2}{|c|}{ Total Skor } & $\mathbf{2 7 7 1}$ & $\mathbf{3 0 0 0}$ \\
\hline
\end{tabular}

Hasil pengujian usability mobile web Tina Tailor mencapai 92.36\% menunjukan bahwa mobile web Tina Tailor sangat layak digunakan oleh pengguna sebagai media penjualan.

\section{KESIMPULAN DAN SARAN}

Melalui pemaparan yang sudah dijabarkan dalam sejumlah bab sebelumnya, bisa disimpulkan bahwasanya tujuan penelitian telah tercapai yakni membuat media penjualan produk berbasis mobile website untuk mengoptimalkan penjualan secara online dan meniadakan perantara pada toko Tina Tailor. Hal ini dibuktikan oleh melalui beberapa pengujian yaitu fuctional testing menggunakan metode pengujian blackbox, compatable testing dengan metode manual menggunakan beberapa device, dan usability testing didapat dari hasil kuesioner ke user target. Hasil pengujian fungsionalitas memperlihatkan data masukan dengan hasil yang diinginkan telah selaras. Hasil pengujian kompatibalitas menunjukan hasil kecepatan yang baik. Sedangkan pengujian kebergunaan berdasarkan learnability, efficiency, memoriability, error, satification menunjukan persentase $92,36 \%$ yang menyatakan bahwa mobile website dinamis Tina Tailor sudah layak untuk digunakan.

\section{DAFTAR PUSTAKA}

[1] S. Kemp, "Digital 2020: Global Digital Overview," Https://Wearesocial.Com/Blog/2020/01/Digital-20203-8-Billion-People-Use-Social-Media, 2020.

[2] M. D. S. Ananda and I. Novita, "Sistem Informasi Penjualan Batik Berbasis Website Pada Toko Kencana Ayu," Idealis, pp. 28-32, 2015, [Online]. Available: http://jom.fti.budiluhur.ac.id/index.php/IDEALIS/articl e/view/2727/1106.

[3] A. Mutiarasari, "IMPLEMENTASI BISNIS ONLINE SYARIAH MELALUI E-COMMERCE DALAM MENINGKATKAN PENJUALAN DI YUKSHIJAB PASURUAN," A $\gamma \alpha \eta$, vol. 8, no. 5, p. 55, 2019.

[4] R. M. A. Wardani and A. Meyliana, "Perancangan Website Sebagai Media Penjualan Online Kain Shibori," Speed - Sentra Penelit. Eng. dan Edukasi, vol. 10, no. 4, pp. 104-110, 2018, [Online]. Available: http://speed.web.id/ejournal/index.php/speed/article/vie $\mathrm{w} / 405 / 398$.

[5] B. Usmanto, R. Immawan, Fauzi, K. P. Sari, and M. I. Mahdi, "Implementasi Web Mobile Sebagai Mediainformasi Pemberdayaan Masyarakat Di Desa Pirngadi," J. Keteknikan dan Sains, vol. 1, no. 1, pp. 3240, 2018, [Online]. Available: http://journal.unhas.ac.id/index.php/juteks/article/view/ 4296."Mobile Web Development.” 2016.

[6] A. Mubarak, "Rancang Bangun Aplikasi Web Sekolah Menggunakan Uml (Unified Modeling Language) Dan Bahasa Pemrograman Php (Php Hypertext Preprocessor)
Berorientasi Objek," JIKO (Jurnal Inform. dan Komputer), vol. 2, no. 1, pp. 19-25, 2019, doi: 10.33387/jiko.v2i1.1052.

\section{BIODATA PENULIS}

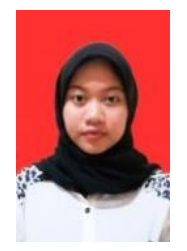

\section{Larasati Lugi Aryaningsih}

Lahir di Jakarta, 17 Juni 2000. Meraih gelar Ahli Madya Desain (A.Md., Ds.) di Politeknik Negeri Media Kreatif Jakarta, Program Studi Konsentrasi Multimedia tahun 2021.

\section{LAMPIRAN}
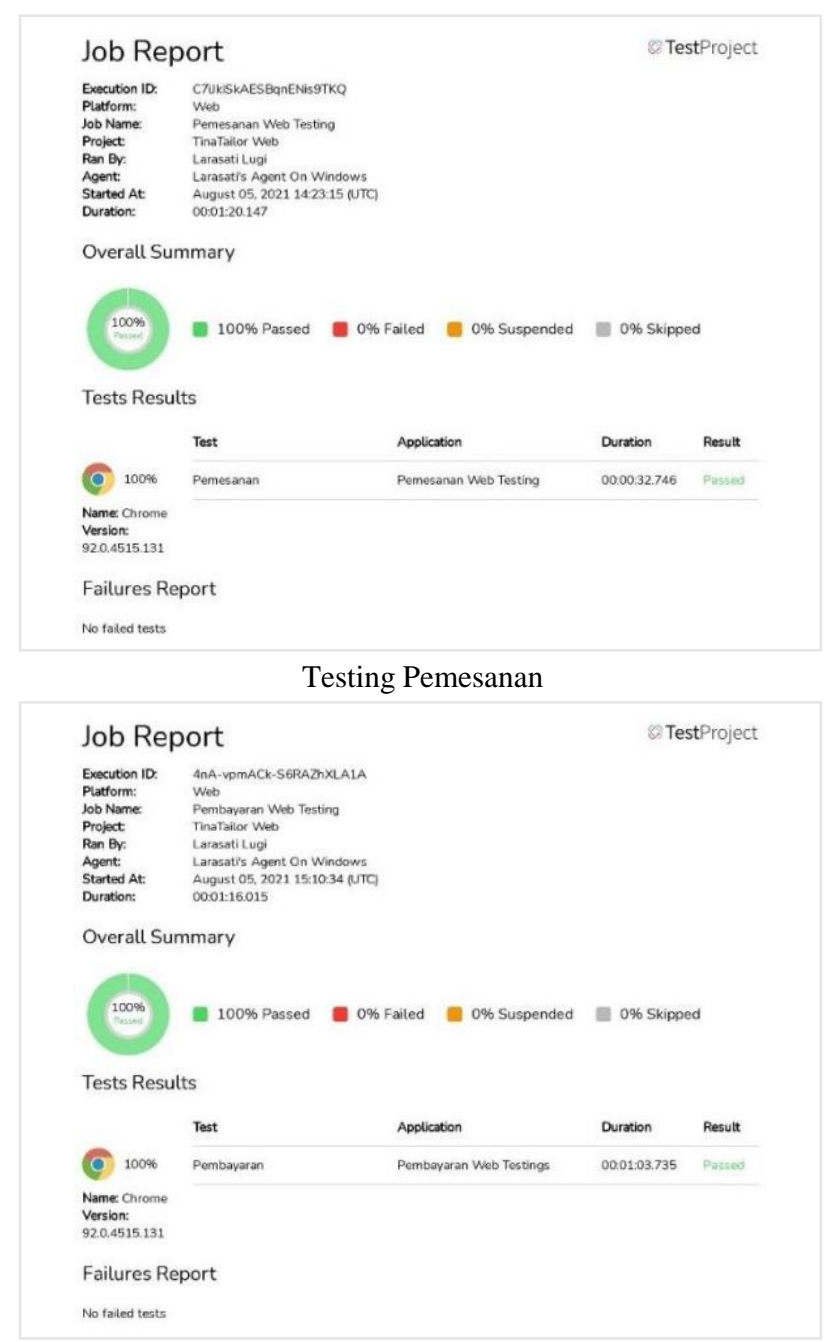

Testing Pembayaran 
